\title{
Food policy councils and local govemments: Creating effective collaboration for food systems change
}

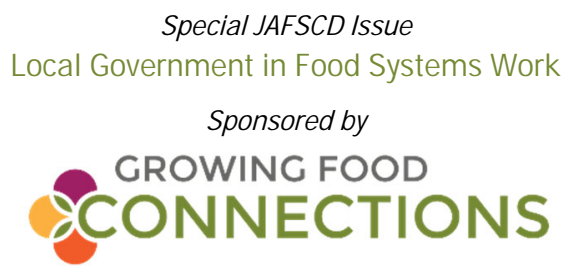

\author{
Clare G upta, ${ }^{\text {a }}$ D ave Campbell, ${ }^{b}$ * and \\ Kate Munden-Dixon ${ }^{c}$ \\ University of California, D avis \\ Jennifer Sowerwined \\ University of California, Berkeley
}

\author{
Shosha Capps ${ }^{\mathrm{e}}$ and G ail Feenstra ${ }^{\mathrm{f}}$ \\ University of California, D avis \\ Julia Van Soelen Kim 9 \\ UC Cooperative Extension Marin County, \\ California
}

Submitted November 13, 2017 / Revised February 5 and April 7, 2018 / Accepted April 10, 2018 /

Published online O ctober 17, 2018

Citation: Gupta, C., Campbell, D., Munden-Dixon, K., Sowerwine, J., Capps, S., Feenstra, G., \& Van Soelen

Kim, J. (2018). Food policy councils and local governments: Creating effective collaboration for food systems

change. Journal of A griculture, Food Systems, and Community D evelopment, 8(Suppl. 2), 11-28.

https:/ / doi.org/ 10.5304/ jafscd.2018.08B.006

Copyright @ 2018 by the Authors. Published by the Lyson Center for Civic Agriculture and Food Systems. Open access under CC BY license.

\begin{abstract}
D rawing data from comparative case studies of 10 California food policy councils (FPCs), this paper describes the nature of the relationships between local governments and FPCs and examines how these relationships support policy-related activities and food systems change. We focus our comparisons on distinct organizational structures, resource

a Clare G upta, D epartment of Human Ecology, University of California, D avis; 1 Shields Avenue; D avis, CA 95616 USA;

+1-650-766-7610; cgupta@ ucdavis.edu

$\mathrm{b} *$ C orresponding author: D ave Campbell, D epartment of Human Ecology, University of California, D avis; 1 Shields Avenue; Davis, CA 95616 USA; +1-530-752-5451; dave.c.campbell@ucdavis.edu

c Kate Munden-Dixon, G eography G raduate Group, University of California, D avis; 1 Shields Avenue; D avis, CA 95616 USA; +1-912-713-5217; kmundendixon@ ucdavis.edu

d Jennifer Sowerwine, D epartment of Environmental Science, Policy and Management, University of California, Berkeley; 130 Mulford Hall \#3114; Berkeley, CA 94720-3114 USA; +1-510-664-7042, jsowerwi@ berkeley.edu
\end{abstract}

flows, and policy activities. All but one of the 10 councils is organized as a multisector community collaborative, rather than as an independent nonprofit organization or a government advisory body. Each includes local government personnel as members and most depend on government resources for their operations, including meeting

e Shosha Capps, UC Sustainable Agriculture Research \& Education Program, University of California, D avis, 1 Shields Avenue, D avis, CA 95616 USA; +1-530-752-5085; sacapps@ucdavis.edu

${ }^{\mathrm{f}} \mathrm{G}$ ail Feenstra, UC Sustainable Agriculture Research \& Education Program, University of California, D avis; 1 Shields Avenue; D avis, CA 95616 USA; +1-530-752-8408; gwfeenstra@ucdavis.edu

g Julia Van Soelen Kim, UC Cooperative Extension Marin County; 1682 Novato Blvd., Suite 150B; Novato, CA 94947 USA; +1-415-473-2708; jvansoelen@ ucanr.edu

\section{Funding Disclosures}

Funding for this project was provided by a competitive grant received from the University of California Division of Agriculture and Natural Resources. 
spaces, facilitation, information, and/ or direct funding. All 10 councils feature regular meetings at which information is shared to build awareness, relationships, and trust, all of which can indirectly shape policy agendas and initiatives. This policy relevant work is feasible even for small councils with few resources. FPC leaders can also seize opportunities by considering the stages of the policy process they hope to influence, the types of policy issues they wish to address, the time frame it may take to realize different types of policy goals, and the degree to which they will seek incremental or more fundamental changes. We find that structural autonomy- being organized outside of the government while maintaining strong collaborations with the government- helps food policy councils retain their independence while promoting more inclusive policy making processes that link community members to the government.

\section{Keywords}

Food Policy Council, Food Policy, Local Food Systems, Local G overnment, Collaboration, Collective Impact, Policy Implementation

\section{Introduction}

A broad and diverse network of civically engaged groups and individuals are working locally to improve food system outcomes. In a growing number of communities, an important institutional mechanism for bringing these groups together and building relationships with local government is a food policy council (Blay-Palmer, 2009; Coplen \& Cuneo, 2015; Sussman \& Bassarab, 2017). A food policy council (FPC) consists of representatives and stakeholders from many sectors of the food system who work with city and state governments to promote the social, economic, and environmental health of local and regional food systems (Harper, Shattuck, Holt-G iménez, Alkon, \& Lambrick, 2009). D rawing data from comparative case studies of 10 California FPCs, this paper describes the nature of the relationships between local governments and food policy councils and examines how these relationships support policyrelated activities and food systems change.

In the mid-1990s, political scientist Kenneth Dahlberg (1994) succinctly characterized the relationship between local governments and food policy: "Food is not seen to be an issue for municipalities" (p. 1). Two decades later, the reality is dramatically different, driven by growing consumer interest in local food, movements for community food security and food justice, and the spread of systems thinking, which views food production and consumption as being inherently linked (Brinkley, 2013; Morgan, 2013; Siddiki, Carboni, Koski, \& Sadiq, 2015; Sonnino, 2009). Supported by professional groups such as the American Planning Association (American Planning Association, 2007), local governments are increasingly engaged in food systems planning and policy, both within communities and across regions (Hodgson, 2012; Pothukuchi, 2009; Pothukuchi \& Kaufman, 1999). To enhance community development and the local agrifood economy, city and county governments have developed plans and enacted policies and regulations (D esign for Health, 2007; Low et al., 2015; McClintock, Wooten, \& Brown, 2012; Neuner, Kelly, \& Raja, 2011; Pothukuchi, 2009; Raja, Picard, Baek, \& D elgado, 2016). Local ordinances now address urban agriculture, backyard livestock, healthy retail incentives and/ or disincentives, regional agricultural land preservation, and food insecurity, among many other issues. Local economic development officials increasingly provide grants, loans, and other incentives to support farmers markets, agri-tourism, aggregation and distribution facilities, or other food system investments.

Previous FPC research has documented their diverse organizational forms, resources, participants, and activities and the high variation across different local contexts (Low et al., 2015). O ur research adds to this literature, with a particular focus on describing and analyzing how local government and FPC leaders collaborate to shape food policies and programs in different local contexts. We also highlight the importance of FPC structural autonomy in supporting their ability to navigate their dual relationships with government and community interests. D rawing primarily on interview data from local food policy council participants, we show how the collaborative mechanisms at work in food policy councils are creating relational ties, trust, and community 
connections- what is often referred to as social capital (Putnam, 2000). By creating space for collaboration and social capital to develop, food policy councils have multiple impacts on their communities. These impacts include, but go beyond, a direct influence on creating laws, regulations, or ordinances. $\mathrm{O}$ ur data show that FPCs help inform multiple stages of the policy process, which begins in agenda setting, proceeds to the formulation and legitimation stages, and eventually is implemented with impacts that can be evaluated (Jones, 1984). Much of the work FPCs do has a relatively low profile, such as fostering information sharing conversations that shape policy agendas over time or partnering with local governments to implement policies that are already enacted. O ur interviews suggest that these types of policy work create positive community impacts in diverse contexts and are feasible even for councils with relatively limited resources.

Research on the L ocal G overnment and F ood Policy Council Relationship

A 2017 survey by Johns Hopkins University researchers provides a descriptive overview of the current state of more than 300 active food policy councils in the U.S. and Canada, including important data regarding their relationship with local government (Sussman \& Bassarab, 2017). It is common for FPCs to have multiple links to government, including having government employees as members, receiving county, city, state, or federal funding, and/ or operating under official government mandates. In this section, we briefly review previous research which has identified two clear trends relevant to understanding FPC-local government relationships. The first is the shift over time in the structural location of most FPCs. The second is the consistent finding that FPCs tend to emphasize programmatic activities as much as--or even more than--direct policy engagement.

Regarding structural location, it has become much more likely that an FPC will take the form of a grassroots coalition, community collaborative, food system alliance or similar structure than be either embedded in government or established as an independent nonprofit organization. The six FPC pioneers in D ahlberg's (1994) study were all structured as citizen advisory bodies within the local government. Much like a planning commission or a human relations commission, the FPCs in the study had both a formal charge from their local government and access to staff resources. Dahlberg (1994) found that resource availability and FPC policy influence depended on a close connection to the mayor's office, which made them vulnerable to shifting fortunes as elections brought new leadership. Second generation FPC leaders began experimenting with different organizational forms (Chen, Clayton, \& Palmer, 2015; Harden, Bain, \& Heim, 2015). Schiff's (2008) comparison of 13 FPCs in the U.S. and Canada found that some were embedded in the government, while others functioned as independent nonprofits, grassroots coalitions, or took a hybrid form. The 2017 Johns Hopkins survey (Sussman \& Bassarab, 2017) found that the most common form of FPC is a countybased grassroots coalition (33\%), followed by being housed in the government (21\%), being an independent nonprofit (20\%), being housed in another nonprofit (19\%), or being embedded in a college, university, or extension office (4\%).

Regarding the degree to which FPCs engage in direct policy-related activity, previous research makes it clear that the FPC label is being applied to collaborations that engage in a diverse and wideranging set of activities, not all of which involve advising or influencing local government policies (Harper et al., 2009; Schiff, 2008; Sussman \& Bassarab, 2017). It is less clear, however, how structural location - being embedded in the government or operating as a nonprofit or community coalition - might interact with other variables to make it more or less likely that an FPC will be successful in shaping local food policies. Many assert that publicly created FPCs tend to focus more on the creation of policy outputs, while nonprofit and grassroots FPCs are more engaged in programmatic activities (Siddiki et al., 2015). Schiff (2008) found that FPCs with government mandates (such as a formal advisory body) focused more on policy work, especially initially, while other FPCs tended to focus on programmatic work initially. Those FPCs only later begin to tackle policy issues, if at all. O ther research suggests that the most important factor in creating policy 
outcomes is a close relationship with local government officials, rather than the organizational location of the FPC (Chen et al., 2015; Coplen \& Cuneo, 2015; DiGulio, 2017). Regardless of structural location, Sherb, Palmer, Frattaroli, and Pollack (2012) found that FPCs are more likely to engage in policy work via problem identification and education, with relatively fewer getting involved in crafting policy proposals or direct advocacy. Broadly applicable conclusions are difficult to come by, as local circumstances vary and what works at one time in an FPC's evolution may not work at another time. A case in point is the rise and eventual dissolution of the Portland Food Policy Council. The dissolution of this FPC has been attributed, in part, to the lack of clarity about the roles of government and nongovernment participants, which undercut effective processes for maintaining adequate resources and access to decision makers (Coplen \& Cuneo, 2015).

Building on this literature, our study seeks a deeper understanding of how FPC and local government leaders navigate the tensions and tradeoffs associated with distinct organizational forms, resource needs, strategic priorities, and desired outcomes, as these are shaped within distinct local contexts. By taking a broader, longer-term view of the policy process, we show how the work of many FPCs is policy relevant, even when it does not result in specific new policies in the short run.

\section{Methodology}

California has more food policy councils than any other state, which is not surprising given its size, the importance of agriculture to the economy, and the presence of a highly active local food movement (Sussman \& Bassarab, 2017). At the time we initiated our research, 26 local food policy councils were listed on the website of the statewide California Food Policy Council (Sussman \& Bassarab, 2017). Using a comparative case study research design (Y in, 2009), we collected data to compare 10 of the 26 local FPCs, some of which choose to call themselves by other names (e.g., food system alliance, food council, agriculture and food alliance). Given our initial research objective of exploring whether and how FPCs use research in their work, the 10 cases were purposely selected to include those that had existing links to UC Cooperative Extension advisor collaborators. The advisors could contribute important insights while providing local connections and background information useful to the statewide research team. As our work progressed, we realized that the data we were collecting could help answer different, equally important questions, including those surrounding FPC relationships with local government.

Given widely varying FPC structures, goals, and activities (Sussman \& Bassarab, 2017) and the tremendous diversity of local contexts and settings across California, putting together a representative sample of California FPCs would be difficult. Nevertheless, our sample- which includes FPCs in Kern, Los Angeles, Marin, Mendocino, Napa, Plumas-Sierra, Sacramento, San Mateo, Sonoma, and Yolo- reflects significant geographic and demographic diversity (see Table 1). For example, the local FPCs vary in scope, with eight FPCs organized in a single county, one in two counties (Plumas-Sierra), and one in a city (Los Angeles). The 10 FPCs include diverse geographic locations, from small, rural counties to very large urban areas, and many mixed locales in between. All 10 FPCs were established during the past decade, in two cases building on earlier efforts that had gone dormant. As we will demonstrate, they also vary significantly according to key distinctions from the literature. That is, they vary in the relative emphasis put on policy versus programs, in organizational structure, and in the nature of their connection to local government.

Key methods used to develop the 10 case studies included semistructured interviews with relevant FPC leaders and stakeholders (Hammer \& Wildavsky, 1993), participant-observation at FPC meetings, focus groups, and document analysis. We conducted over 60 interviews, five to six for each of the 10 councils. This allowed us to gain a richer depth and breadth of perspectives than in previous FPC case studies (see Appendix for interview guide). Interviews covered FPC information sources and use of research, council structure and/ or membership, resources, programmatic or policy priorities, and notable achievements. Background information on the interviewee and the history of the food policy council was also gathered 
Table 1. Basic Comparisons of California FPCs in Sample (by descending size of population)

\begin{tabular}{|c|c|c|c|c|c|c|c|}
\hline FPC & $\begin{array}{c}\text { Year } \\
\text { Established }\end{array}$ & Scope & $\begin{array}{l}2015 \\
\text { Population } \\
\text { (Califomia } \\
\text { Department of } \\
\text { Finance } \\
\text { estimates) }\end{array}$ & $\begin{array}{l}2014 \text { Total Value } \\
\text { of Agricultural } \\
\text { Production } \\
\text { (US\$1,000; no } \\
\text { timber; CDFA) }\end{array}$ & Locale & FPC Organizational Form & $\begin{array}{l}\text { Types of Local Government } \\
\text { Personnel Engaged }\end{array}$ \\
\hline Los Angeles & $\begin{array}{l}2011 \\
\text { relaunch } \\
\text { (1990s } \\
\text { original) }\end{array}$ & City & $4,031,000$ & $\$ 230,068$ & Highly urban & $\begin{array}{l}\text { Multisector collective } \\
\text { impact initiative }\end{array}$ & $\begin{array}{l}\text { Elected officials, agency heads } \\
\text { and staff }\end{array}$ \\
\hline Sacramento & 2014 & County & $1,481,803$ & $\$ 495,403$ & Mostly urban & Community collaborative & Mid- and frontline agency staff \\
\hline Kem & 2013 & County & 880,387 & $\$ 7,552,327$ & $\begin{array}{l}\text { Mostly rural with one } \\
\text { large urban area and } \\
\text { large scale agriculture }\end{array}$ & Community collaborative & Mid- and frontline agency staff \\
\hline San Mateo & 2006 & County & 759,155 & $\$ 152,153$ & $\begin{array}{l}\text { Mostly urban and } \\
\text { suburban }\end{array}$ & Community collaborative & Mid- and frontline agency staff \\
\hline Sonoma & 2009 & County & 499,352 & $\$ 902,858$ & $\begin{array}{l}\text { Mixed urban/ suburban } \\
\text { with some more rural } \\
\text { areas }\end{array}$ & Community collaborative & Mid- and frontline agency staff \\
\hline Marin & $\begin{array}{c}2012 \\
\text { relaunch } \\
(1998 \\
\text { original })\end{array}$ & County & 261,798 & $\$ 100,953$ & $\begin{array}{l}\text { Mixed urban and } \\
\text { suburban with some } \\
\text { more rural areas }\end{array}$ & Community collaborative & $\begin{array}{l}\text { Elected officials, mid-and } \\
\text { frontline agency staff }\end{array}$ \\
\hline Yolo & 2013 & County & 211,813 & $\$ 801,205$ & $\begin{array}{l}\text { A few cities surrounded } \\
\text { by agricultural areas }\end{array}$ & Community collaborative & $\begin{array}{l}\text { Elected officials, mid-and } \\
\text { front-line agency staff }\end{array}$ \\
\hline Napa & 2011 & County & 140,898 & $\$ 720,833$ & $\begin{array}{l}\text { Mixed urban and } \\
\text { suburban with some } \\
\text { more rural areas }\end{array}$ & $\begin{array}{l}\text { Formal government } \\
\text { advisory board }\end{array}$ & Agriculture commissioner \\
\hline Mendocino & 2010 & County & 88,163 & $\$ 174,200$ & $\begin{array}{l}\text { Rural with some small } \\
\text { cities }\end{array}$ & Community collaborative & Mid- and frontline agency staff \\
\hline Plumas-Sierra & 2007 & $\begin{array}{l}\text { Two } \\
\text { counties }\end{array}$ & 23,069 & $\begin{array}{r}\$ 67,347 \\
\text { (combined) }\end{array}$ & $\begin{array}{l}\text { Rural with some small } \\
\text { cities }\end{array}$ & Community collaborative & Mid- and frontline agency staff \\
\hline
\end{tabular}


from interviews and documents. Focus groups were held at one regional FPC gathering and one statewide meeting of the California Food Policy Council.

The interviews were recorded, transcribed, and coded by a member of the research team using the NVivo (version 11) software coding program. Following procedures outlined in Miles and Huberman (1994), we used both preset and emergent codes. The former coincided with specific interview guide questions and the latter proved to be important when multiple respondents mentioned the same topic or theme. Content analysis of the transcribed and coded interviews and other data was used to analyze emergent, cross-cutting themes and key principles (Krippendorff \& Bock, 2009). These ideas were then cross-checked for validity and refined by comparing them to memos generated by the lead researchers for each case study, and through a series of iterative discussions among the seven members of the research team.

\section{Descriptive Findings}

In this section, we present basic descriptive findings that provide important background and context for the comparative findings that we discuss in the next section. We focus on three topics introduced in previous literature: (1) structural form and location vis-à-vis local government; (2) membership and resource connections to local government; (3) policy areas in which the FPCs are working.

Structural F orm and L ocation Compared to the latest data on organizational form from the Johns Hopkins survey, our sample is heavily weighted toward FPCs that operate as multisector coalitions or collaboratives. That is, they are neither embedded in government nor established as independent nonprofit organizations (although some councils operate under an affiliation with a nonprofit fiscal sponsor). This is true in nine of 10 cases. Napa was an outlier because it served as an advisory body in the county agriculture commissioner's office. To some degree, the collaborative form of FPC organization is rendering the old questions about "what is the best FPC location" irrelevant. A well-functioning cross- sector network can take advantage of "insider" connections (primarily via agency staff participation but also in some cases elected officials or highlevel public agency leaders) while remaining "outside" governmental restrictions (such as prescribed meeting processes or attempts by agency and/ or elected officials to alter the FPC agenda). But the network form poses other tradeoffs, particularly those driven by community size. In large communities, the number of players that have to be organized into a collaborative, and the corresponding need for staff with sophisticated networking and convening skills, is heightened, but so is the possibility of doing "big things" together. For example, supported by a nonprofit fiscal sponsor and by close connections to the mayor's office, the Los Angeles FPC is convening hundreds of organizations and over 1,000 individuals into a "collective impact" initiative, a term used to describe deliberate efforts to build multisector alliances that work to change targeted indicators of community wellbeing (Flood, Minkler, Hennessey Lavery, Estrada, \& Falbe, 2015; Kania \& Kramer, 2011). By contrast, in smaller settings it can be easier to get key stakeholders to the table, but more difficult to do "big things" due to staff and resource limitations. For example, the Plumas-Sierra council includes just a half dozen or so members from the adjoining rural counties, constituting what one interviewee calls a "loose-knit tribe." The dramatic demographic contrasts between Los Angeles and Plumas-Sierra (see Table 1) illustrate the widely varying community contexts in which FPCs operate.

\section{M embership and Resource C onnections to} $\mathrm{L}$ ocal $\mathrm{G}$ overnment

All 10 FPCs have local government employees among their membership. Typically these are midlevel and/ or front-line (service delivery) staff from various public agencies who attend FPC meetings and events as part of their existing job duties. Local government personnel often are critical to an FPC's ability to function, especially in community settings where there are few nonprofits or community-based organizations with the capacity and infrastructure to support collaborative work. Their contributions range from serving as catalysts 
for setting agendas, to offering support resources such as meeting space or facilitation, to providing connections to other government resources. The most frequently represented agencies in our sample include Cooperative Extension, public health, environmental health, and the County Agricultural Commissioner; however, this can vary significantly across councils and over time, depending on whether a good match exists between the strategic priorities of the FPC and those of the public agencies. In only a few cases, members of the county Board of Supervisors, the City Council, or their staff were regular attendees. In Los Angeles, the FPC was originally closely tied to the mayor's office and got a significant boost in legitimacy from this connection. They built on that start to become one of the only FPCs in our sample to engage higher-level public officials, including the heads of the county's large government agencies (see table one).

In a few cases, government staff played key roles in facilitating or convening the FPC; in others, leadership came from nonprofit organizations or community activists. Notably, the social location of these leaders varied in our sample: a county department head, a highly-networked group of food activists, and a well-connected "insider" with strong ties to local government leaders and agencies, etc. The particular starting point mattered less than the ability of these leaders to (1) strengthen the credibility of the FPC as a trusted resource for food policy work with various local government officials, (2) ensure that the agendas of the FPCs focused on policy engagement rather than on programs alone, and (3) sustain an organizational structure that weds strong local government connections with meaningful community engagement. The policy successes mentioned by our respondents were built on these foundations put in place by the leaders. O ur findings echo the trenchant early observation by Dahlberg (1994) that having skilled leaders who can make connections and ensure that "the right things happen at the right time" (p.10) is perhaps the single most important building block for the success of food policy councils.

While we did not collect comprehensive data on funding, at least five of the 10 FPCs reported having received funding from their local government. In the case of the Napa FPC, this funding is a recurring part of the budget which the county Board of Supervisors provides to the Agriculture Commissioner's office. In three counties, Mendocino, San Mateo, and Sonoma, county funding to the Health Department is channeled to support FPC activities, including staff support and, in the latter two cases, paying for facilitation services provided by the Ag Innovations consultant group. In Marin, funding from the Board of Supervisors is provided through the county Cooperative Extension office. If one includes the time which government staff participants spend on FPC meetings and activities that are supported by their government position, it is clear that local government funds directly or indirectly support all 10 FPCs.

Policy A reas in which the Councils are W orking Respondents from all 10 FPCs could point to some aspect of public policy that they influenced, either directly or indirectly. They offered a variety of evidence, including legislative victories. They also mentioned cases where the FPC played a convening role that brought together policy allies or initiated discussions which, over time, shaped the food policy agenda of the local government. O ne of the most common scenarios reported was that FPCs sought to influence the agricultural element of the County General Plan, but many other policy topics were mentioned. Illustrative examples of policy achievements mentioned by respondents are provided in Table 2.

Taking advantage of their affiliation with the California Food Policy Council (or their geographic proximity to the capital, in the case of Sacramento), some local FPCs also have assisted in passing or implementing state policies, such as urban agriculture legislation and the Nutrition Incentive Matching G rant Program. In a few cases, individual members of local FPCs take on policy work that may have been identified in the FPC setting without necessarily doing it as a representative of the FPC.

Expanding access to healthy food is a frequently mentioned policy priority among the FPCs we studied, and many interviewees view addressing the needs of marginalized populations, 
Table 2. Selected Examples of Policy Achievements Cited by FPC Respondents

\begin{tabular}{ll}
\hline Policy Achievement & Local FPCs \\
\hline $\begin{array}{l}\text { Inserting food and agriculture } \\
\text { language into county general plans }\end{array}$ & $\begin{array}{l}\text { Marin, Mendocino, Plumas- } \\
\text { Sierra, Yolo, San Mateo }\end{array}$ \\
\hline Food Day Resolution & Los Angeles, Marin \\
\hline “Approved source" language adopted to facilitate sales of local produce & Mendocino, Napa \\
\hline Urban agriculture and land use ordinance & Mendocino, Sacramento, Napa \\
\hline City will oversee renting public and/ or private land for community gardens and farming & Napa \\
\hline Bee-keeping ordinance & Napa, San Mateo \\
\hline Food systems workers minimum wage increase & Sacramento \\
\hline Backyard livestock ordinances & Napa, Sacramento \\
\hline Inserted language into county crop report & San Mateo \\
\hline Farm ombudsman created & Yolo \\
\hline Right-to-farm ordinance & Yolo \\
\hline Food Action Plan & Sonoma \\
\hline Urban agriculture goals inserted into city of Los Angeles Sustainability Plan & Los Angeles \\
\hline Good Food Purchasing Policy & Los Angeles \\
\hline Supported passage of state AB 1321 (Nutrition Incentive Bill) & Kern \\
\hline
\end{tabular}

particularly around food insecurity, as a key motivation for the work that they do. We found that issues surrounding farmworkers and others food system laborers are less frequently a focus; however, at least one FPC was part of a local effort to raise the minimum wage. We continue to explore these concerns and outline our conclusion in the following sections.

\section{Comparative Findings}

This section draws on our comparative analysis of the data to probe more deeply into the nature of how and why these FPCs are engaging in policy work. We note (1) the degree to which they prioritize policy work; (2) their roles at different stages of the policy process; and (3) different approaches to creating intentional, long-term strategies to achieve food systems change via policy collaborations with local government.

D egree to which F PC s Prioritize

Policy-related A ctivities

We found broad variation in the degree to which the FPCs in our sample engage directly in policy related activities. At one end of the spectrum, some FPCs go out of their way to avoid policy which they view as inherently divisive and counterproductive to their goal of bringing diverse stakeholders together. At the other end, some FPCs see policy change as central to their broader objective of changing the food system. Those FPCs make policy work a high priority. In middle of the spectrum are FPCs who may emphasize policy as specific opportunities arise while spending the majority of their time initiating community projects or programs. Los Angeles, Napa, and Sacramento are three examples where a policy focus tended to be more intentional and sustained, as indicated by the ability of respondents to articulate policy priorities, activities, and outcomes.

Collaborations with $\mathrm{L}$ ocal G overnment at $D$ ifferent Stages of the Policy Process "Policy" is sometimes equated with the formal processes of passing new laws or regulations, yet the policy process begins much earlier in agenda setting and continues much later in implementation and evaluation (Jones, 1984). O ur respondents 
spoke to policy activities at multiple stages of the policy process, beginning with the early conversations that set the stage for policy priorities to emerge. As noted earlier, local government personnel participate in regular FPC meetings as part of their existing responsibilities, sharing information from their own work and learning from other FPC participants. This mutual education function is one of the key roles FPCs play. The knowledge, trust, and social capital built in FPC settings indirectly influences policy agendas by altering the perspectives of key decision-makers, identifying potential policy allies, or bringing to light previously hidden issues.

An example illustrating this type of indirect policy work can be seen in the Yolo Food and Ag Alliance. Yolo FPC meetings feature participant updates in a round-robin style. Interviewees suggest that this way of informally sharing information is quite helpful. It educates them about what is happening, introduces them to new ideas, people, and projects, initiates unexpected connections, and builds the foundation for emerging partnerships and collaborative activity. Sometimes information sharing helps with problem identification. For example, discussions about cannabis led the FPC to stage a larger public forum on the topic, which in turn began to generate ideas for solutions or alternative strategies. These discussions are fluid and often occur across multiple contexts in which the FPC members and their allies might be working. They can germinate quickly in some cases or more slowly in others, since getting the attention of policy-makers is often difficult (Stone, O rr, \& Worgs, 2006). Having meetings and associated opportunities to raise issues publicly elevates the potential for eventual policy attention and action. One respondent summed up the Yolo FPC meetings as being "an intentional forum for accidental collaboration." Indeed, information sharing and mutual education - which can often lead to serendipitous collaborations- is one of the most common functions and features across all 10 of our cases, building the social capital connections that inform and support more direct policy activity.

In another example, a San Mateo respondent explained that the county's progress on the issue of regulatory streaming of farm ponds stemmed, in part, from FPC discussions and connections. Because of the relationships built in the FPC and the information being shared, the county public health officer became a supporter of actions that someone in their position might typically have resisted. As the respondent put it, "That's insane. Like, that's so esoteric, right? It's because of this network that he understands that regulatory streamlining is essential to water supply, is essential to ag viability, is essential to local food, and is part of public health."

Some local government collaborations reported by our FPC respondents focused on how existing policies are implemented in a community. In other cases, public agencies have projects that can benefit from the ability of FPCs to solicit community input or provide community education. In some cases, FPCs are trying to implement smallscale projects and can benefit from access to local government relationships or resources. Sometimes these mutually beneficial activities rise to the level of a semiformal partnership for a limited period of time. More often, they evolve informally as needs arise or opportunities present themselves. For example, the Plumas-Sierra Food Council and the public health department teamed up to increase the rate of eligible residents who take advantage of Supplemental Nutrition Assistance Program Education (SNAP-Ed) benefits, calling upon FPC members and their organizations to help with community education and outreach. In another example related to Plumas-Sierra, farmer concerns over restrictive government permitting practices were aired at the FPC. This prompted a government representative to go back to his home agency and seek appropriate changes. Another key "win" in this rural area was getting the food bank supply trucks to come to the community twice a week rather than just once. Another small win involved encouraging a local community college to offer its first-ever course in sustainable agriculture. These types of changes can often fall under the radar of what is considered policy work, but in fact they often represent the kinds of tangible policy engagement that are feasible even for councils with relatively limited resources. Typically, they involve working in tandem with government employees who are either FPC members or working partners 
of those members.

Another example of FPCs helping their local government implement policy is the G eneral Plan campaign initiative of the Sacramento FPC. California Senate Bill 1000 took effect in 2017 and strengthens how general plans in all California jurisdictions address environmental justice. The council has established a monthly meeting with the staff of the Sacramento County Planning D ivision to advise on SB1000 compliance in their general plan update and is in the process of trying to set up a similar advisory relationship with the city of Sacramento. While the council primarily will advise on issues of health and food, the diversity among its membership gives it the expertise to inform other issue areas and to help assist with the required community meetings in each planning area.

Intentional, L onger-T erm Strategies to A chieve F ood Systems C hange A few respondents were able to articulate longerterm policy engagement strategies in which FPCs align their policy priorities with those of local government officials and agency staff, or vice versa. Where priorities already overlap, and the changes sought are more incremental in nature, alignment is more easily achieved in the short-run. By contrast, when deeper or more fundamental food system changes are pursued- including efforts to better include marginalized populations in policy processes- it can often take longer to see results. This is because patient coalition building and community organizing by FPCs gradually shifts or alters the priorities of local government officials. The Sacramento, Napa, and Los Angeles case studies show contrasting ways in which this can be done.

\section{Sacramento}

The Sacramento council was originally structured with an executive board, a steering committee, and four working groups. These working groups were organized around topics of interest that were identified during early meetings: Local Procurement Policy, School Food Environment, Environmental Sustainability, and Community Food Access. There was a strong desire on the executive board for all initiatives to be fully community-led; however, some groups struggled with the broad mandate and with insufficient funding and staff support. As a result, the council has been restructuring itself around "campaigns." The goal was to create a wider range of ways for community members to be involved in specific actions without needing to make a longer-term commitment or to join a subject area working group. The restructuring keeps in place the open, community-led structure of the council. It also represents one way in which the council is making an intentional effort to be more inclusive of a broader set of community participants.

Sacramento's current campaigns were developed through a strategic planning process and member survey, and each supports a long term policy goal of the council. For example, one campaign is focused on ensuring that the Sacramento City Unified School D istrict builds a central kitchen with deep community engagement. Another campaign is focused on elevating food as a priority element in the Sacramento city and county general plans. These campaigns serve multiple purposes: providing a vehicle for residents to get involved and learn how policy affects their life and/ or work, maintaining council activity and momentum, building relationships, and making progress toward community-identified goals. The shift to campaigns helps the council maintain its focus on long-term policy objectives. It is also a strategic decision to structure the council in such a way that it can hold space for community leadership and mobilization. At the same time, the clearly focused goals of the campaigns have made it easier for government staff to justify attending council meetings since they can point to a clear connection to their agency mission.

Agencies and officials engaged with the Sacramento FPC include the county Nutrition Education O besity Prevention Program, the California D epartment of Conservation, the Metropolitan Air Quality Management D istrict, several school districts, and the offices of a local city council member and state senator. For these government staff, the council becomes a source of expertise around particular issues, a partner in community engagement, or an ally on a particular issue or priority. In turn, these government employees can provide 
insight to the council on how to navigate the bureaucracy or how to connect with key government personnel or processes. For example, on the Central Kitchen Campaign, the council is working with the Sacramento City Unified School D istrict's superintendent, school board, and staff. After securing the school district's agreement to build the central kitchen, the campaign is now focused on ensuring the facilities are built with community engagement and that there are opportunities for education, training, and connections with local farms. Overall, the inclusive campaign structure and the intentional policy commitments of Sacramento FPC leadership have facilitated a lengthy list of policy-related achievements.

\section{N apa}

The Napa case illustrates how operating as a formal advisory board to the local county government can facilitate strategic alignment but also bring challenges. The council, known as the Napa Local Food Advisory Council, originated in 2010. The former Napa agricultural commissioner proposed the creation of the FPC. Nearing retirement, he wanted to take meaningful action to address both food insecurity and lack of agricultural diversity in the county. Using his political capital, he facilitated a visioning process with community members representing different sectors and interests. He framed local food production as an endeavor that could augment, rather than replace, the dominant wine industry. The council- which included representatives from agriculture, health and nutrition, environmental health, and planning, as well as chefs and restaurant owners- was charged with making recommendations to the agricultural commissioner and the county board of supervisors. The commissioner funded the council's baseline activities and provided staff time and supplies to run meetings out of the department's budget, while securing additional funding through the board of supervisors for larger projects.

Initially, the council focused on conducting land inventories for farming opportunities and evaluating local regulations to promote the sale of locally grown and processed foods in Napa. Its agenda shifted, however, when the founding agricultural commissioner retired and a new commissioner took office. After that change, , the council's primary policy and project activities are more aligned with the department's traditional mission--one that emphasizes interpreting and enforcing agricultural regulations. So, while the council remains structurally aligned with the agricultural commissioner's office, and can point to policy successes (e.g., a bee-keeping ordinance), some members feel a growing gap between their original objectives of food system change and their current activities. In addition, because the council is an official government body, it must follow governmental protocols that- despite their intention - can sometimes discourage inclusive community participation. These include open meeting laws, strict agendas, and codified voting policies. The council also cannot receive certain kinds of external funding. At the same time, the council can count on levels of staff support and resources that many FPCs that are not embedded in government struggle to obtain.

\section{L os A ngeles}

The Los Angeles case showcases an ambitious attempt to facilitate strategic policy alignment on a large scale and over a long period of time. While in many respects Los Angeles is an outlier in our sample, given its large size and the significant resources available to support its work, the case still holds broader lessons for food policy councils interested in crafting more deliberate and intentional approaches to achieving policy change. Adjusted for scale, many of these approaches might be feasible in other localities.

The Los Angeles food policy council defines itself as the backbone organization of a collective impad initiative (Flood et al., 2015; Kania \& Kramer, 2011), with the goal of "providing overall strategic direction, facilitating dialogue between partners, managing data collection and analysis, handling communications, coordinating community outreach, and mobilizing funding" (Hanleybrown, Kania, \& Kramer, 2012, p. 6). The key structure is composed of a leadership council of 40 representatives from different sectors of the food system. The leadership council is drawn from a broader base of food system representatives that includes 1,000 individuals and over 300 public, private, 
nonprofit, and academic organizations. The collective impact model shifts the focus from changing specific policies or programs to articulating broadscale community changes. The task then becomes aligning policy and programmatic activities across a wide range of organizations to achieve a collective impact.

The council has fostered civic engagement in food policy work by providing a trusted venue for a two-way flow of information among elected officials, government agencies, and diverse stakeholders. At the center are a core group of paid staff, including an executive director and a leadership board that includes food system leaders from the public, private, and nonprofit sectors. D ecentralized working groups engage communities and community-based organizations in the process of setting policy and project priorities, bringing their proposals to the leadership board for final decisions. Finally, the council's networking activities serve as the fluid interface with the public in the form of town halls and public events. Upwards of 60 organizations and individuals attend various public events to learn from and inform council priorities. This multidimensional governance structure has proven highly effective in keeping both government and community stakeholders at the table by providing all parties with meaningful opportunities to align interests and achieve food systems change.

For example, community food security advocates used council connections to partner with the Los Angeles Community Redevelopment Agency on a successful corner market conversion program. This program ultimately developed into the highly acclaimed Healthy Neighborhood Market Network. Another bottom-up example involves street food vending. Through stakeholder meetings, the council discovered strong community love of and interest in promoting street food vending-- often referred to as Angelino cuisine--but, at the time, street food vendors were illegal. Leveraging council connections with the D epartment of Public Health, an FPC working group (now reconstituted as the "LA Street Vendor Campaign") began to develop a legal permit system for sidewalk vending, including requirements that vendors near schools provide healthy food. The FPC's food waste working group strategically invited key decision-makers from the Bureau of Sanitation to their meeting; as a result, the working group was subsequently invited to develop the food donation component of the new waste recycling program. Finally, one of the hallmark successes of the Los Angeles FPC, the Good Food Purchasing Policy, grew out of a multistakeholder working group that brought together labor, environmentalists, big food buyers, farmers, distributors, and processors. Its goal was to develop a good food procurement policy that improves the local and regional food system by implementing standards in five key categories: (1) local economies; (2) environmental sustainability; (3) valued workforce; (4) animal welfare; and (5) nutrition. The policy was eventually endorsed by the FPC leadership board, the mayor's office, and the city council. Because of broad local government endorsement, and the fact that the deputy director of the Los Angeles Unified School District sat on the council, the district adopted the procurement policy in 2012.

Throughout its work, the Los Angeles FPC has confronted the tension between bringing key decision-makers to the table while maintaining the trust of community-based organizations representing more marginalized communities. This was particularly true in its early days when the FPC had strong ties to the mayor's office and was viewed by some as promoting an insider agenda. Recent efforts to implement the collective impact approach, and deliberate efforts to engage the issues of marginalized communities, have helped build trust and secure a more inclusive set of collaborations.

\section{Discussion: The Benefits of Structural Autonomy}

O ur comparative case study analysis deepens the understanding of how effective relationships between food policy councils and local government can be initiated, structured, and sustained. As discussed in our literature review, a major question raised in previous studies is whether FPCs are better off embedding themselves within the local government or operating outside of the government. Without definitely answering this question, our cases nevertheless make a strong case for the 
importance of organizing the FPC to maximize its structural autonomy. In this way, the FPC controls both its policy agenda and the processes by which it can work. Contrary to some earlier findings (DiGulio, 2017), we argue that the politics of location do matter. O ur findings suggest that when a council is housed within a government agency, as in Napa's agricultural commissioner's office, there is greater pressure to align with the mission of that entity defined by the current leadership. This restricts the ability of the FPC to respond to a broader base of community concerns. This concern is lessened, but only slightly, if the council is under the mantle of a part of the government whose responsibilities are to all constituents and programs. This was the case, initially, when the FPC in Los Angeles was part of the mayor's office. But even that arrangement alienated some community constituencies, who later came on board when the FPC established itself as an independent collaborative. Councils housed outside of the government, like the Sacramento FPC, can engage in strategic temporary alliances or partnerships with specific agencies that align with their particular campaign goals at the time without needing to comply with or adhere to the mission of any particular government agency over the long-term. Positive working relationships with government entities, therefore, do not necessarily need to be formalized and/ or institutionalized to lead to successful policy outcomes or to build trust and legitimacy. However, in the case of the Los Angeles FPC, originating as a political project of the mayor's office did provide the council a high degree of legitimacy and political cache among food system leaders from the business, nonprofit, and government sectors. The council leveraged this legitimacy to build a powerful leadership board and achieve a high number of policy successes.

FPCs organized as grassroots collaboratives are well positioned to ensure that an inclusive and broad range of community voices are contributing to policy discourse, formation, and evaluation. The relatively informal settings and procedures of the councils we studied are more accessible and inviting to community participants than are formal government processes and procedures. Consistent with the earlier work of Siddike et al. (2015), we find that the degree to which the council is internally organized to foster inclusive processes also influences how effectively it is able to engage with local government and policy. For example, the working group structure adopted by the Los Angeles FPC has been able to bring together key food system decision-makers from the public, private, and nonprofit sectors and to hold a space for a two-way flow of information between community stakeholders and local government. In the case of Sacramento, the specificity of the FPC's campaignoriented goals and objectives-along with a fluid membership structure that allows participation without having to be involved in all decisions and actions of the council- make it easier for government employees or activists focused on particular issues to participate. In addition, the decentralized, or horizontal, structure of the Sacramento council also intentionally creates the opportunity for authentic and inclusive public engagement in defining campaign priorities and fosters active engagement in campaigns.

At the same time, many FPCs benefit from having leaders who bring to the work extensive political connections, relevant policy experience, and intentional policy agendas. The best policy outcomes seem to reflect a prudent blend of inclusive community-based processes and the strategic use of insider connections.

\section{Conclusion}

While there is no single, ideal model for a local government-FPC relationship, our in-depth case comparisons demonstrate approaches that can assist local governments and food policy councils to work more collaboratively and effectively to advance equitable local food system policies and programs in their communities. D eploying these approaches in any particular local context requires intentional leadership than can assess organizational resources, identify potential allies, enlist community participation, and seek immediate and long-term opportunities for policy alignment. FPCs can seize opportunities by considering the stages of the policy process they hope to influence, the types of policy issues they wish to engage, the time frame it may take to realize different types of policy goals, and the degree to which they will seek incremental 
or more fundamental changes. The particular strategies or approaches that councils pursue often involve combining these elements in creative ways that are suited to the opportunities and constraints of their particular circumstances, including resource availability.

For their part, local governments can take a number of steps to engage effectively with food policy councils. These can include (1) participating in FPCs by dedicating staff to attend and participate in FPC meetings and events, or providing other forms of in-kind support (such as meeting spaces); (2) partnering with FPCs to help educate the public on available government resources or to gather advice on the best strategies for implementing public policies; (3) embracing FPC policy proposals that advance local economic development, food security, anti-hunger, or related goals; (4) engaging with FPCs as sounding boards for developing new policy ideas and proposals and as incubators of new civic leaders; or (5) helping develop and launch FPCs in communities that do not have one.

Both FPCs and local governments can benefit from a greater emphasis on equity and inclusion, both in who is at the table in local planning and policy processes and in the centrality of equity issues on the policy agenda. $\mathrm{On}$ the one hand, the fact that most FPCs focus on issues of food access is putting equity issues on the front burner of their policy discussions. On the other, many FPCs still have relatively limited representation from marginalized groups among their regular participants, and local governments still tend to be most responsive to more powerful local interests. Unless they are intentional about inclusive processes and change agendas, FPCs and local governments risk simply reproducing some of the same inequalities that they might otherwise ameliorate.

Given our relatively small sample, it is not clear how generalizable these findings may be. We hope other researchers can test our ideas in a more systematic way, and we look forward to a continuing conversation with practitioners as they seek food system change and effective relationships with local governments.

\section{Acknowledgments}

The authors wish to thank the food policy council members who generously gave their time to inform our research team. O ur work was aided in important ways by partnerships with local University of California Cooperative Extension Advisors Virginia Bolshakova, Holly G eorge, Margaret Johns, and Rachel Surls.

\section{References}

American Planning Association. (2007). Policy guide on community and regional food planning. Retrieved from https:// www.planning.org/ policy/ guides/ adopted/ food.htm

Blay-Palmer, A. (2009). The Canadian pioneer: The genesis of urban food policy in Toronto. International Planning Studies, 14(4), 401-416. https:// doi.org/ 10.1080/ 13563471003642837

Brinkley, C. (2013). Avenues into food planning: A review of scholarly food system research. International Planning Studies, 18(2), 243-266. https:// doi.org/ 10.1080/ 13563475.2013.774150

Chen, W.-t., Clayton, M. L., \& Palmer, A. (2015). Community food seaurity in the U nited States: A survey of the scientific literature (Vol. 2). Baltimore, Maryland: Johns Hopkins Center for a Livable Future. Retrieved from https:// www.jhsph.edu/ research/ centers-and-institutes/ johns-hopkins-center-for-a-livablefuture/ research/clf publications/pub rep desc/CLF-Surveys-Community-Food-Security-Updated-Report.html

Coplen, A. K., \& Cuneo, M. (2015). D issolved: Lessons learned from the Portland Multnomah Food Policy Council. Journal of A griculture, F ood Systems, and C ommunity D evelopment, 5(2), 91-107. https:/ / doi.org/ 10.5304/ jafscd.2015.052.002

Dahlberg, K. (1994). F ood policy councils: The ex perience of five cities and one county. Paper presented at the joint meeting of the Agriculture, Food, and Human Values Society and the Society for the Study of Food and Society, Tuscon, Arizona.

Design for Health. (2007). Planning information sheet: Promoting food access with omprehensive planning and ordinanœes. Retrieved from http:// designforhealth.net/ wp-content/ uploads/ 2012/ 12/ BCBS_ISFood 090107.pdf 
Journal of Agriculture, Food Systems, and Community D evelopment

ISSN: 2152-0801 online

https:/ / www.foodsystemsjournal.org

DiGiulio, L. (2017, August 1). Food policy councils: Is there a best structure? [Blog post]. Retrieved from http:/ / livablefutureblog.com/2017/ 08/ food-policy-councils-best-structure

Flood, J., Minkler, M., Hennessey Lavery, S., Estrada, J., \& Falbe, J. (2015). The collective impact model and its potential for health promotion: O verview and case study of a healthy retail initiative in San Francisco. H ealth E ducation \& Behavior, 42(5), 654-668. https:/ / doi.org/ 10.1177/ 1090198115577372

Hammer, D ., \& Wildavsky, A. (1993). The open-ended, semistructured interview: An (almost) operational guide. In A. B. Wildavsky (Ed.), Craftways: $0 \mathrm{n}$ the organization of scholarly work (2nd ed.) (pp. 57-102). Piscataway, New Jersey: Transaction Publishers.

Hanleybrown, F., Kania, J., \& Kramer, M. (2012, January 26). Channeling change: Making collective impact work. Stanford Social Innovation Review. Retrieved from https:// ssir.org/ articles/ entry/ channeling_change making_collective impact work\#

Harden, N., Bain, J., \& Heim, S. (2015). Cultivating collective action: The ecology of a statewide food network. Retrieved from http:/ / hdl.handle.net/ 11299/ 175654

Harper, A., Shattuck, A., Holt-G iménez, E., Alkon, A., \& Lambrick, F. (2009). F ood policy councils: L essons learned. Retrieved from https:/ / foodfirst.org/ publication/ food-policy-councils-lessons-learned/

Hodgson, K. (2012). Planning for food acess and community-based food systems: A national scan and evaluation of local comprehensive and sustainability plans. Chicago: American Planning Association.

Jones, C. O . (1984). A n introduction to the study of public policy (3rd ed.). Belmont, California: Wadsworth Publishing.

Kania, J., \& Kramer, M. (2011). Collective impact. Retrieved from https:/ / ssir.org/ articles/ entry/ collective impact

Krippendorff, K., \& Bock, M. A. (2009). The content analysis reader. Thousand Oaks, California: Sage Publications.

Low, S. A., Adalja, A., Beaulieu, E., Key, N., Martinez, S., Melton, A., .. Jablonski, B. B. R. (2015). Trends in U S local and regional food systems: Report to C ongress (AP068). Retrieved from https:/ / naldc.nal.usda.gov/ download/ 60312/ PDF

McClintock, N., Wooten, H., \& Brown, A. H. (2012). Toward a food policy "first step" in Oakland, California: A food policy council's efforts to promote urban agriculture zoning. Journal of A griculture, Food Systems, and Community D evelopment, 2(4), 15-42. https:/ / doi.org/ 10.5304/ jafscd.2012.024.009

Miles, M. B., Huberman, A. M. (1994). Q ualitative data analysis: A n expanded sourœebook (2nd ed.). Thousand Oaks, California: Sage Publications.

Morgan, K. (2013). The rise of urban food planning. International Planning Studies, 18(1), 1-4. https:/ / doi.org/ 10.1080/ 13563475.2012.752189

Neuner, K., Kelly, S., \& Raja, S. (2011). Planning to eat? Innovative local government plans and policies to build healthy food systems in the United States. Buffalo, New York: Food Systems and Healthy Communities Lab.

Pothukuchi, K. (2009). Community and regional food planning: Building institutional support in the United States. International Planning Studies, 14(4), 349-367. https:/ / doi.org/ 10.1080/ 13563471003642902

Pothukuchi, K., \& Kaufman, J. L. (1999). Placing the food system on the urban agenda: The role of municipal institutions in food systems planning. A grialture and $\mathrm{H}$ uman V alues, 16 (2), 213-224. https:// doi.org/ 10.1023/ A:1007558805953

Putnam, R. D . (2000). Bowling alone: The collapse and revival of A merican community. New Y ork: Simon and Schuster. https:/ / doi.org/ 10.1145/ 358916.361990

Raja, S., Picard, D ., Baek, S., \& D elgado, C. (2016). Rustbelt radicalism: A decade of food systems planning practice in Buffalo, New Y ork (USA). Journal of A griculture, Food Systems, and C ommunity D evelopment, 4(4), 173-189. https:// doi.org/ 10.5304/ jafscd.2014.044.015

Scherb, A., Palmer, A., Frattaroli, S., \& Pollack, K. (2012). Exploring food system policy: A survey of food policy councils in the United States. Journal of A griaulture, F ood Systems, and C ommunity D evelopment, 2(4), 3-14. http:/ / dx.doi.org/ 10.5304/ jafscd.2012.024.007

Schiff, R. (2008). The role of food policy councils in developing sustainable food systems. Journal of $H$ unger \& E nvironmental N utrition, 3(2-3), 206-228. https:/ / doi.org/ 10.1080/ 19320240802244017

Siddiki, S. N., Carboni, J. L., Koski, C., \& Sadiq, A.-A. (2015). How policy rules shape the structure and performance of collaborative governance arrangements. Public A dministration Review, 75(4), 536-547.

https:// doi.org/ 10.1111/ puar.12352 
Sonnino, R. (2009). Feeding the city: Towards a new research and planning agenda. International Planning Studies, 14(4), 425-435. https:/ / doi.org/ 10.1080/ 13563471003642795

Stone, C., O rr, M., \& Worgs, D . (2006). The flight of the bumblebee: Why reform is difficult but not impossible. Perspectives on Politics, 4(3), 529-546. https:/ / doi.org/ 10.1017/ S1537592706060348

Sussman, L., \& Bassarab, K. (2017). Food policy council report 2016. Retrieved from http:/ / www.foodpolicynetworks.org/ food-policy-resources/ ?resource=933

Yin, R. K. (2009). C ase study research: D esign and methods (4th ed.). Thousand O aks, California: Sage Publications. 


\section{Appendix. Food Policy Council Interview Protocol}

Thank you for agreeing to talk with us. Before we begin, is it OK with you if we record this interview? [Let them know about how we will handle the confidentiality of the data.]

About you

1. What positions do you hold in your home organization (or in the broader community)?

2. About how long have you been involved with the FPC and why?

3. What unique perspective does your organization bring to the table?

4. What are you hoping your FPC can accomplish in the long term? What would success look like?

\section{Background on the FPC}

5. What are some of the priority issues your food policy council currently focuses on? Have these changed much over time?

a. Probe: specifically what policy issues does your council address (by understanding the issues, analyzing them, exploring options, or acting on them in some way)?

6. Is there anything unique about this community that you feel is important to understanding how your FPC works? (e.g., particular challenges, historical legacies, environmental or social conditions, etc.)

a. Probe, only if not already known: How is the FPC organized? Is it a non-profit, government associated or other?

Mapping exercise: Relationships, Information Sources, Use of Systematic Data

7. We are interested in where your FPC might get policy relevant information (particularly from research or other systematically collected data). It could be from academics or other sources. Help us get a picture by drawing a map of the organizations and people who provide information or knowledge to the FPC, and talk about how it's shared with the council members.

8. Are there any noteworthy examples of how this flow of knowledge and information changed your thinking/approach to your work with the FPC? If yes, please tell us the story.

9. You've talked about current information flows. Are there kinds of information or sources you feel are missing from your food policy council?

10. Are there examples of how your FPC has partnered with a research organization to answer specific policy questions, evaluate policy impact, or provide other policy relevant information? How has this gone? Have any particular policy successes resulted?

11. Probes: (if not already mentioned):

a. What about policy related partnerships or information sharing with other FPCs or the state FPC?

b. What ties are there to UCCE, UC, or other researchers/ research institutions? How have these come about and what value have they brought? 


\section{Lessons learned and future suggestions}

12. Have you learned any lessons you might share about working with researchers or research institutions?

13. Do you have specific ideas or ways you would like to more effectively engage UCCE and/or other research institutions in food policy work?

14. If you had access to researchers to research and collect data on topics that would be helpful to the work of the FPC, what would you have them do? What would be your 'wish list'?

15. Is there anything else you think we should know? 